ISSN:2656-4270 (Online) 1410-4466 (Print) Accredited by Ministry of Research, Technology, and Higher Education with the ranking of Sinta (S4) SK NO.28/E/KPT/2019, 26th September 2019
Buletin Penelitian Sosial Ekonomi Pertanian Fakultas Pertanian Universitas Haluoleo

2021:23(1):10-15

http://ojs.uho.ac.id/index.php/sosek

doi: http://dx.doi.org/10.37149/sosek.v23i1.15565

\title{
THE CONTRIBUTION OF OIL PALM PARTNERSHIPS TO INCREASED INCOME OF PLASMA FARMERS: A STUDY AT PT. WINDU NABATINDO LESTARI (WNL)
}

\author{
Indra kurniawan $^{\left.1^{*}\right)}$, Olivia Elfatma ${ }^{1)}$ Subakho Aryo Saloko ${ }^{1)}$ Heri Setyawan ${ }^{1)}$ \\ ${ }^{1}$ Akademi Komunitas Perkebunan Yogyakarta \\ ${ }^{*}$ Corresponding author: indrakurniawan@akpy-stiper.ac.id
}

To cite this article:

Kurniawan, I., Elfatma, O., Saloko, S., \& Setyawan, H. (2021). The Contribution of Oil Palm Partnerships to Increased Income of Plasma Farmers: A Study at PT. Windu Nabatindo Lestari (WNL). Buletin Penelitian Sosial Ekonomi Pertanian Fakultas Pertanian Universitas Haluoleo, 23(1), 10 - 15. doi:http://dx.doi.org/10.37149/bpsosek.v23i1.15565

Received: December 17, 2020; Accepted: February 21, 2021; Published: February 22, 2021

\begin{abstract}
The income level of smallholder farmers can only meet their daily needs due to the location's remote location and the difficulty of communication access. Based on this, the Government seeks to formulate policies that are expected to have a real impact on increasing the productivity of smallholdings and improving the welfare of farmers. One of the efforts made is the Primary Member Cooperative Credit (KKPA). The purpose of this research is to examine the impact of the partnership program at the Windu Nabatindo Lestari (WNL) company in the KKPA scheme, a program to improve the welfare of plasma farmers. The research method is descriptive analysis with a qualitative approach using purposive sampling. Research respondents were 60 plasma farmers. Data collection techniques include field observations, in-depth interviews with questionnaires, and analysis of company documents. The results showed an increase in the welfare of plasma farmers after the partnership program. The partnership program at the Windu Nabatindo Lestari (WNL) company under the KKPA scheme positively impacts the welfare of plasma farmers in Pundu Village, Cempaga Hulu District East Kotawaringin, Central Kalimantan. The frequency of the number of plasma farmers who experienced increased income before and after the KKPA program was $83.3 \%$.
\end{abstract}

Keywords: cooperative; farmer welfare; KKPA; palm oil; partnership program

\section{INTRODUCTION}

Palm oil is an agricultural commodity with great potential as an oil producer and contributes to providing the world's vegetable oil needs. Then Indonesia's oil palm plantations are also one of the largest in the world, which consist of State Large Companies (PBN), Large Private Companies (PBS), and People's Plantations (Ningsih \& Fitrisia, 2020); (Febryanto, Tri Endar Suswatiningsih, 2017); (Agustina, 2016). The Government continues to strive to make policies that are expected to increase the productivity of smallholder plantations and improve the welfare of farmers. One of the efforts is the partnership system (nucleus-plasma), where PBS/PBN acts as the nucleus, and smallholder farmers work as plasma farmers.

The PBS/PBN partnership program aims to act as the core and provide guidance, production facilities, technical advice, and marketing. At the same time, plasma farmers carry out production functions (Fini Yuliska, 2019). The partnership program in KKPA (Kredit Koperasi Primer Anggota) is a form of credit scheme with soft terms provided by the Government through the Company (Aquaculture et al., 2006). (Persero) Permodalan Nasional Madani (PT. PNM) to primary cooperatives with individual members, then distributed to members. The period of plantation development is quite long, and the payback period is also long, so this type of credit is included in investment credit. Investment credit is a working capital loan. The capital is given by the Bank to the Primary Cooperative and passed on to the cooperative members to finance the members' businesses to be more productive (Sari, 2017). This credit is returned or paid in installments according to a predetermined period based on a mutual agreement with the Bank. The number of credit installments, 
including interest, is calculated with a certain percentage of the gross proceeds of the plantation by the agreement between the Bank and the cooperative.

Cooperatives act as implementers and providers of KKPA (executing agent) or as a channel (challenging agent) (Agustina, 2016). In its role as a distributor, the cooperative has no responsibility for the risk of credit repayment. The Bank carries out credit Agreements with each member of the KKPA recipient, which is known by the cooperative management (Matualage et al., 2019). In the implementation of the Credit Agreement, the members are represented by the collective leadership. Therefore, KKPA recipient members must make a Power of Attorney to the cooperative management. In carrying out the development of partnership gardens, cooperatives receive interest subsidies from the Government. This interest subsidy is only valid during the development period (maximum five years for oil palm). It is subject to change by applicable regulations (Saputra et al., 2017).

Cooperatives have several tasks, including (1) Submission of project proposals to be financed by KKPA, (2) Selection of eligible members to be financed, (3) Supervision of the use of plantations financed by KKPA, (4) Guidance for members, (5) Collection of KKPA installments, (6) Administration of the KKPA provider and the installments as the executor of the KKPA provider, the cooperative is responsible for the risk of total credit return, and (7) the signing of the Credit Agreement is carried out by the Cooperative Management, (Sari, 2017); (Agustina, 2016).

Smallholder farmers from Pundu Village, Cempaga Hulu Sub-district, East Kotawaringin, Central Kalimantan only earn enough to meet their daily needs. This is due to the remote location and limited access. The Government is trying to make policies that are expected to increase the productivity of people's plantations and improve the welfare of farmers. Oil palm farmers have more income if their plantation productivity is high (Setyawan et al., 2020). Then one of the efforts made is the Primary Member Cooperative Credit (KKPA). One of them is by establishing a KKPA in Pundu Village in collaboration with PT. Windu Nabatindo Lestari (WNL), a subsidiary of PT. Bumitama Gunajaya Agro (BGA) Group. This collaboration is expected to increase the income of Pundu residents, especially smallholder farmers. The effectiveness of a successful partnership and its impact on the community is undoubtedly fascinating to study. If this collaboration has a positive effect on oil palm farmers, it will undoubtedly determine the potential for the sustainability of this program. The purpose of this study was to examine the contribution of oil palm partnerships in the Windu Nabatindo Lestari (WNL) company in improving the welfare of plasma farmers, especially in terms of income.

\section{MATERIALS AND METHODS}

This research uses a qualitative approach, which is trying to get them as complete information as possible about the Oil Palm Plantation Partnership Program. This research was conducted at PT. WNL who is in Pundu Village, Cempaga Hulu District, East Kotawaringin, Central Kalimantan. Sampling using purposive sampling method, namely taking samples with specific criteria by the objectives of the research criteria for the program to conduct in-depth interviews. The number of samples or respondents taken in this study was 60 plasma oil palm farmers. The study used 3 data collection techniques: observation, interviews with questionnaires, and analysis of company documents. The results of the research used a qualitative approach.

\section{RESULTS AND DISCUSSION}

Partnership program at PT. WNL started in 2004-2005 is presented in Figure 1. The cooperative collects data by adjusting the available land area, meaning that people who own land are the main priority as members of plasma farmers. The data collection process also includes several things that are the main requirements to become plasma farmers, including (1) People living around the company, (2) Joining cooperative members, (3) Age above 17 years or already married, (4) For people who do not own land, it will be divided from village land if the village owns the land.

PT. WNL area is $5,750 \mathrm{Ha}$, divided into 2,875 members from 9 legally registered villages. The company's presence in the community is felt to impact positively, such as availability of transportation, increasing the fulfillment of life needs, access to information, and communication. Problems before the emergence of this company, such as access to transportation between villages and cities, were complex and took a long time. This condition affects the fulfillment of their daily needs by utilizing their agricultural products. Still, after the company's existence, they feel at ease in terms of mobility to the city so that it indirectly makes it easier for them to fulfill their daily needs. Limited access to information and communication causes residents to be isolated. This was proven when the opening of oil palm plantations. Many people did not understand oil palm commodities. However, after the company's existence, they get convenience in exchanging information because they can use 
communication tools optimally. This limited access means that the community of Pundu and its surroundings have never received a partnership program. The people of Pundu Village and its environs, on average, get income from rubber plantations from generations of inheritance and work as field farmers. Their income is not significant and only enough to meet their daily needs. After the existence of this partnership program, the revenue of plasma farmers will increase and help improve their lives. The partnership program presented by the company in Pundu Village received an assessment from plasma farmers.

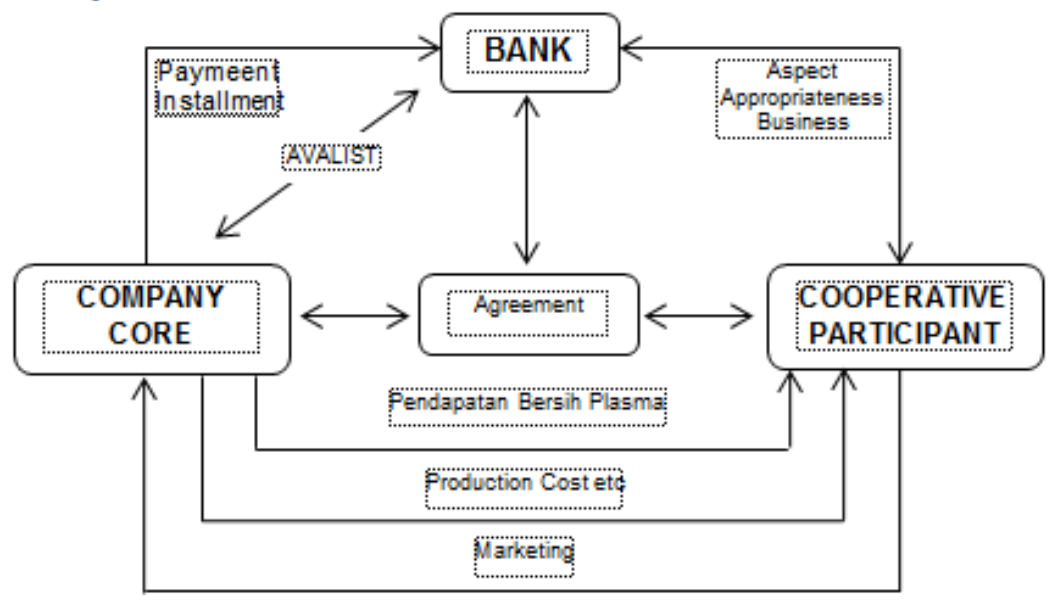

Figure 1. KKPA circulation that takes place at PT. WNL

Their evaluation of this partnership program is critical because it will show whether this program is acceptable or not. The evaluation of the partnership program is directly related to improving the economy of farmers so that they can be felt in real terms. As shown in Table 1.

Table 1. Farmers' assessment of the partnership program

\begin{tabular}{lccc}
\hline & Evaluation & Frequency & $\%$ \\
\hline Very Positive & & 6 & 10,0 \\
Positive & & 42 & 70,0 \\
Less Positive & & 10 & 16,7 \\
Not Positive & Amount & 2 & 3,3 \\
\hline & & 60 & 100 \\
\hline
\end{tabular}

The analysis obtained results: A total of $70.0 \%$ of the plasma farmers considered that this partnership program had a positive impact, meaning that the program implemented by the company had a real impact that was by the local community's needs. If it was related to the types of community needs, especially in times of Currently, the program implemented by the company does not have a harmful impact at all. Hence, the program has a vast and real impact. This is in line with the opinion (Ghouri et al., 2019) that partnerships with strategic planning can lead to both success and success. Even $10 \%$ of respondents rated that the partnership program had a "very positive" impact. This proves that the program implemented by PT. WNL is very beneficial for the local community. However, there is also a "less positive" assessment of $16.7 \%$ and "not positive" as much as $3.3 \%$. Based on this, it shows that behind the benefits and impacts that have been felt, some people still have not felt the effect, so it is necessary to innovate and improve the program to impact the wider community. Then, in addition to assessing the impact on the implemented program, there is also an assessment of economic improvement.

The assessment of economic improvement is presented in table 2. Based on Table 2, as many as $83.3 \%$ stated that this partnership program "helps" the economy of plasma farmers because the results can be an additional income to meet their daily needs and other needs. The purpose of this assistance is that at first, the surrounding community only planted seasonal crops such as corn, chili, eggplant, and one plantation crop, namely rubber plants, where the results of farming have not been able to provide more results for the family life of the community in Pandu Village. Then enter PT. WNL, who apply a partnership pattern to the Pandu village community with the partnership implemented by the company, farmers in Pundu village are coordinated to carry out oil palm planting where PT WNL will purchase the results. Then from the partnership program, the farmers and the community there finally felt a tangible impact on the agenda. Initially, they only get income from one 
type of work. Now, they also get income from planting oil palm programmed by PT. WNL. Supported by the statement (Parris \& Broussard, 2020) that the partnership can help economically disadvantaged people, this is due to additional family income so that this partnership program is felt to help the surrounding community.

Table 2. Partnership program for economic improvement of plasma smallholders

\begin{tabular}{lccc}
\hline & Economic Improvement & Frequency & $\%$ \\
\hline Help & 50 & 83,3 \\
Not helpful & & 4 & 6,7 \\
Do not know & Amount & 6 & 10 \\
\hline & Amo & 60 & 100 \\
\hline
\end{tabular}

Furthermore, $6.7 \%$ of respondents answered "not helpful," and $10 \%$ of respondents answered, "don't know." Based on the observations, this is due to the lack of understanding of some of the Pandu village communities on the partnership program implemented by PT. WNL so that they are not diligent and not earnest in addressing the partnership program. They think that the partnership program will not have much impact on their family's economy. While the reality on the ground the program provides more benefits. This is a challenge for companies in carrying out socialization because good socialization is one of the supporters of success in social partnership programs. After all, not all village communities can immediately accept a new program (Lawrence et al., 2020). The real impact on increasing the income of the Pundu village community is by increasing their income in the form of money, where money is a genuine benchmark felt by the Pundu village community.

The increase in the income of plasma farmers is shown in Figure 2. Before the partnership program, the community's income was IDR 500.000 to 1.000 .000 per month, and the community with rubber plantations was IDR 1.000 .000 to 2.000 .000 per month. Then after becoming oil palm plasma smallholders, their income increased between IDR 3.000.000 to 4.000 .000 per month because their source of income increased from oil palm plasma plantations (D. Sinta, 2013); (Andriani, 2017).

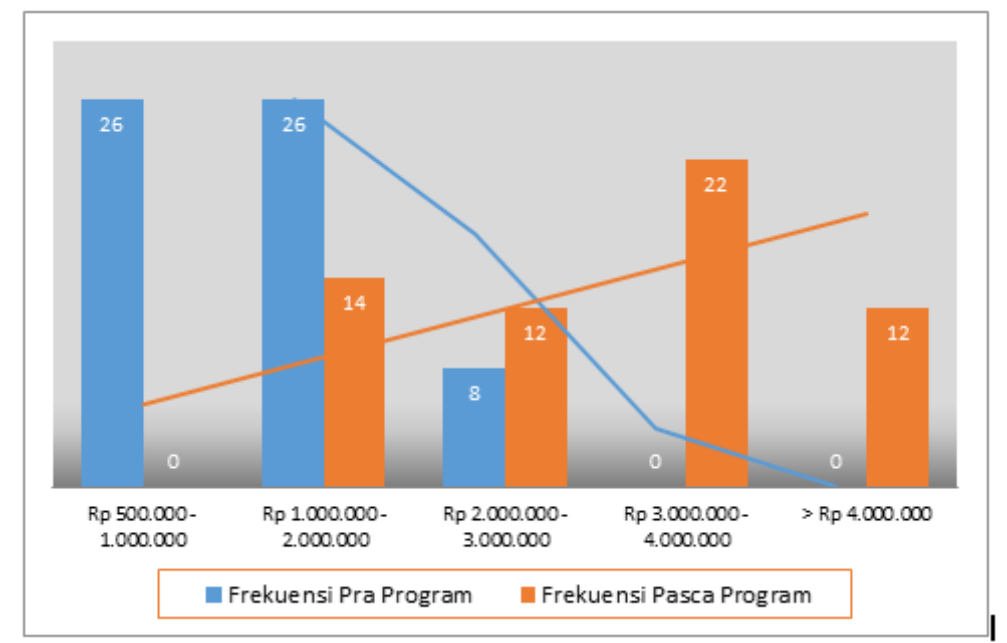

Figure 2. Farmer Income Before and After the Partnership Program

This shows that by participating in the partnership program PT. WNL to become part of the plasma farmers can improve the economy of family life. Economic improvement certainly impacts the ability to meet the needs of daily life. In general, it has a positive impact on improving the welfare of the farming community in Pundu village. Based on this, as time goes by, the program implemented can positively influence other communities to participate in the partnership program implemented by PT. WNL.

The income data of farmers after the partnership program can be reduced to information on the presentation of the increase in the income of plasma farmers in the research area, which is presented in Figure 3. Based on the graph in Figure 3. Shows the value of a significant increase in income, where initially before PT's partnership. PT. WNL farmers in Pundu village only have an income of around IDR 500.000 - IDR 1.000.000. But now, after the partnership program, farmers' income in Pundu village has increased to IDR 3.000.000 - IDR 4.000.000. the increase in revenue from these figures can increase the purchasing power of the Pundu village community to be higher. 
Supported by statements from (Yen Chu et al., 2020) that increasing family income can increase their purchasing power, both daily consumption and their purchasing power for long-term durable goods (Doğanlar et al., 2020).

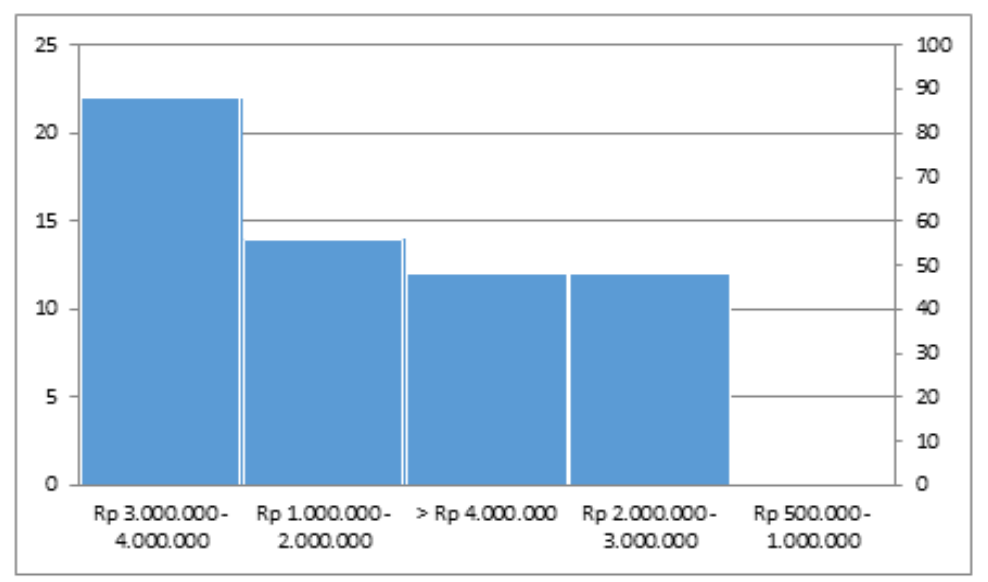

Figure 3. Frequency of the number of plasma farmers who experienced an increase in income before and after the KKPA program

\section{CONCLUSIONS}

The partnership program carried out by the company PT Windu Nabatindo Lestari (WNL) with the Primary Member Cooperative Credit (KKPA) scheme has contributed to increasing income and improving the welfare of plasma farmers.

\section{REFERENCES}

Agustina. (2016). Pola Kemitraan Antara Pemerintah, Pihak Swasta Dan Masyarakat Dalam Pengembangan Sektor Perkebunan Kelapa Sawit: Studi Dinas. Journal IImu Sosial, Politik Dan Pemerintahan, 5(2), 36-41.

Akuakultur, P. S., Sarjana, P., Sosial, F., Ekonomi, F., \& Jenderal, U. (2006). A Relationship Model Of Nuclear-Plasma In Aquaculture Industry Of. Journal LPPM Universitas Jenderal Soedirman Purwokerto, 6(1), 57-69. https://media.neliti.com/media/publications/118316-ID-none.pdf

Andriani, E. (2017). Analisis Sumber Pendapatan Petani Kelapa Sawit. Agrisep, 16(2), 145-154. https://core.ac.uk/download/pdf/228571672.pdf

D. Sinta. (2013). Analisis Pendapatan Usaha Dan Tingkat Kesejahteraan Rumah Tangga Petani Kelapa Sawit Di Kecamatan Budong - Budong Kabupaten Mamuju Tengah. Journal of Chemical Information and Modeling, 53(9), 1689-1699.

Doğanlar, M., Mike, F., \& Kızılkaya, O. (2020). Testing the validity of purchasing power parity in alternative markets: Evidence from the fourier quantile unit root test. Borsa Istanbul Review. https://doi.org/10.1016/j.bir.2020.12.004

Febryanto, Tri Endar Suswatiningsih, H. W. (2017). Kajian Produktivitas Kebun Plasma Dan Non Plasma Di Desa Titian Resak Kecamatan Seberida Kabupaten Indragiri Hulu Provinsi Riau. Jurnal Agromast, 2(1). http://36.82.106.238:8885/jurnal/index.php/JAl/article/view/297/272

Fini Yuliska, Y. S. (2019). Kecukupan Pendapatan Petani Sawit Inti Plasma Pola Pir Kelapa Sawit Desa Koto Baru Kecamatan Singingi Hilir Kabupaten Kuantan Singingi Provinsi Riau Fini. Jurnal Buana, 1.

Ghouri, A. M., Akhtar, P., Shahbaz, M., \& Shabbir, H. (2019). Affective organizational commitment in global strategic partnerships: The role of individual-level microfoundations and social change. Technological Forecasting and Social Change, 146(February), 320-330. https://doi.org/10.1016/j.techfore.2019.05.025

Lawrence, A., Wong, J. L. G., \& Molteno, S. (2020). Fostering social enterprise in woodlands: Challenges for partnerships supporting social innovation. Forest Policy and Economics, 118(May), 102221. https://doi.org/10.1016/j.forpol.2020.102221

Matualage, A., Hariadi, S. S., \& Wiryono, P. (2019). Pengelolaan Kebun Kelapa Sawit Dalam Pola Kemitraan Inti Plasma Ptpn li Prafi Dengan Petani Suku Arfak Di Manokwari, Papua Barat. JSEP (Journal of Social and Agricultural Economics), $12(1), 19$. https://doi.org/10.19184/jsep.v12i1.6897 
Ningsih, Y. S., \& Fitrisia, A. (2020). Perekonomian Masyarakat Perkebunan Plasma Kelapa Sawit Jorong Jambak Kecamatan Luhak Nan Duo ( 2003-2019 ). Jurnal Kronologi, 2(3), 24-37.

Parris, D. L., \& Broussard, K. (2020). Feeding Collective Impact: How to Foster Cross-Sector Partnerships that Build Innovative Solutions for Social Change. Organizational Dynamics, 2019, 100803. https://doi.org/10.1016/j.orgdyn.2020.100803

Saputra, I. M. G. D., Anggreni, I. G. A. A. L., \& Dharma, I. P. (2017). Pola Kemitraan Usaha Tani Kelapa Sawit Kelompok Tani Telaga Biru dengan PT. Sawindo Kencana melalui Koperasi di Kabupaten Bangka Barat Provinsi Bangka Belitung. Jurnal Agribisnis Dan Agrowisata (Journal of Agribusiness and Agritourism), 6(2), 249-258. https://doi.org/10.24843/jaa.2017.v06.i02.p08

Sari, D. (2017). Evaluasi Program Kredit Koperasi Primer Anggota (KKPA) PT Perkebunan Nusantara V. Sosio E-Kons, 9(1), 9. https://doi.org/10.30998/sosioekons.v9i1.1683

Setyawan, H., Kurniawan, I., Setiawan, K., \& Listianto, H. (2020). The Welfare Analysis Of Oil Palm Smallholder Farmers In Pangkalan Banteng Sub-District, Central Kalimantan. 4270.

Yen Chu, M., Hua Law, T., Hamid, H., Hook Law, S., \& Chai Lee, J. (2020). Examining the effects of urbanization and purchasing power on the relationship between motorcycle ownership and economic development: A panel data. International Journal of Transportation Science and Technology, December, 1-11. https://doi.org/10.1016/j.ijtst.2020.12.004 